\title{
Cerebral amyloid angiopati
}
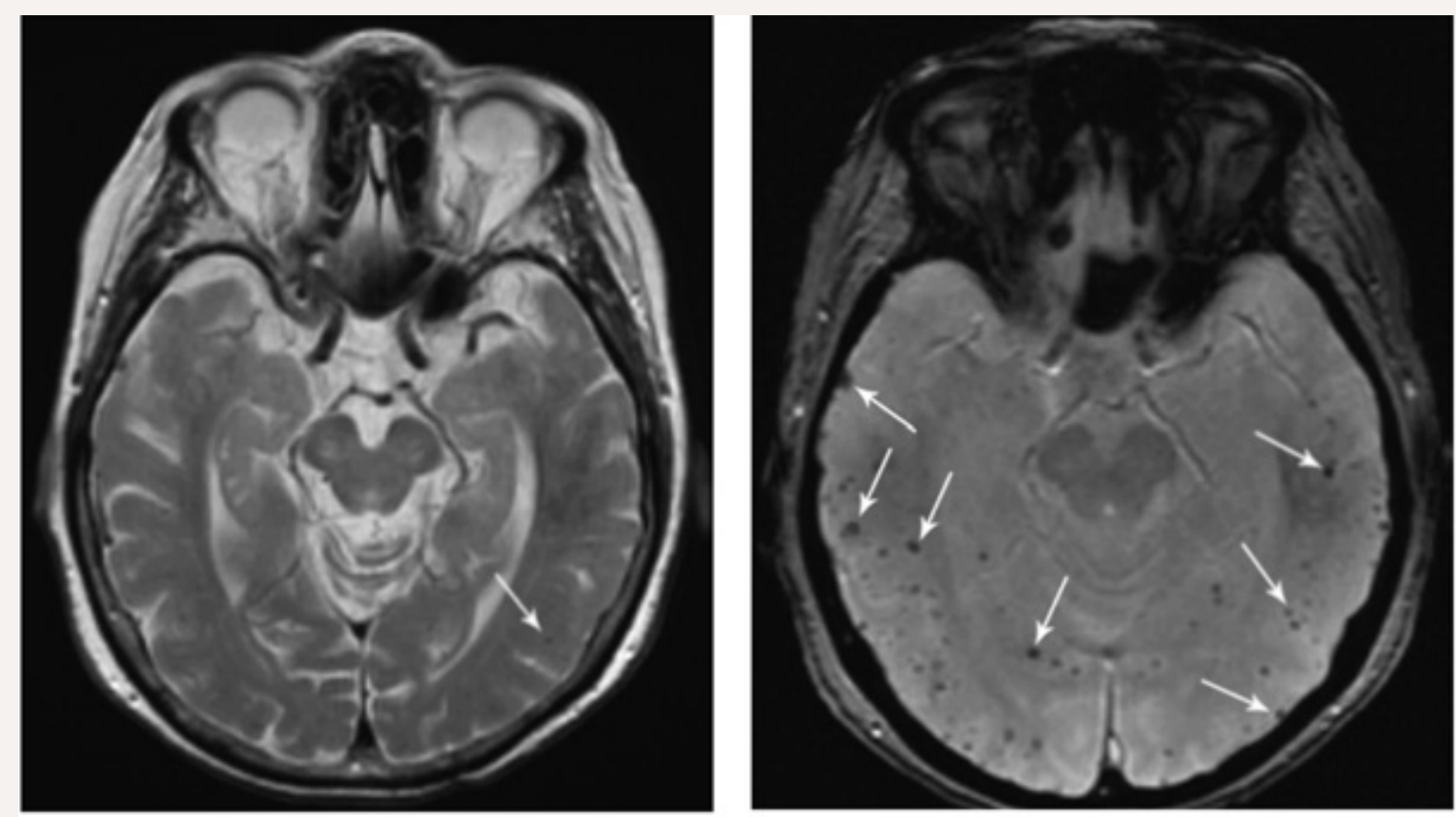

Cerebral amyloid angiopati (CAA) forårsakes av amyloide avleiringer i de leptomeningeale og kortikale kar i cerebrum og cerebellum. Sykdommen er ikke relatert til systemisk amyloidose. Avleiringene fører til fibrinoid nekrose og mikroaneurismer i affiserte kar. Ruptur av aneurismer gir mikroog makroblødninger. Insidensen stiger med økende alder. Slik angiopati er en viktig årsak til hjerneblødning hos eldre.

Mikroblødninger kan føre til residiverende episoder med transitoriske nevrologiske utfall. Blødningene etterlater hemosiderinavleiringer kortikalt-subkortikalt. Disse visualiseres ikke på CT og er vanskelig å se på vanlige MR-bilder. Bildet til venstre viser en mulig avleiring på venstre side, markert med pil, som ble tolket som uspesifikk, ellers normale funn. Symptomene mistolkes ofte som transitoriske iskemiske attakker (TIA). Gjentatte mikroblødninger kan fører til langsomt progredierende demens.

På MR med spesielle gradientekkosekvenser trer avleiringene tydelig frem. Gammelt blod fremstår som mørkt (signal void). Mikroblødningene fremstår da som flere punktformige avleiringer i periferien. På bilde til høyre ses flere avleringer, de største er markert med piler.

Pasienter med cerebral amyloid angiopati bør ikke bruke antikoagulasjon. Ved kjent atrieflimmer og samtidig mistanke om slik sykdom må behandlingen avgjøres i hvert enkelt tilfelle. Tidlig diagnose og seponering av forebyggende blodfortynnende medisinering kan forhindre ytterligere blødninger og forfall i pasientens kliniske tilstand.

\section{Anagha P. Parkar apparkar@gmail.com \\ Radiologisk avdeling}

\section{Sabine Nore}

Medisinsk avdeling

\section{Cornelia Fischer-Bredenbeck}

Radiologisk avdeling

Haraldsplass Diakonale Sykehus 5009 Bergen

\section{Oppgitte interessekonflikter: Ingen}

Manuskriptet ble mottatt 7.5. 2010 og godkjent 2.9. 2010. Medisinsk redaktør Michael Bretthauer. 